\title{
Data Preparation to Address Heterogeneity in Time Use Data Based Activity Modelling
}

\author{
Takeshi Okada $^{1}$, Yuto Shoda ${ }^{1}$, Yohei Yamaguchi ${ }^{1}$, Yoshiyuki Shimoda ${ }^{1}$ \\ ${ }^{1}$ Graduate School of Engineering, Osaka University, Suita, Japan
}

\begin{abstract}
Stochastic person-based activity models play an important role in the prediction of the realistic time-series energy demand for residential buildings. These models generally use input parameters developed based on timeuse data. This paper evaluates how the adopted data preparation approach alters the variability in simulated activities among households. Four simulation cases were developed in the study, representing 1) clustering, 2) regression and 3) integrated approaches combining the first two. A comparison of the results indicates the integrated approach to be the most advantageous. Finally, a strategy to enhance heterogeneity in the simulated household activity for residential energy demand modelling is discussed.
\end{abstract}

\section{Introduction}

The modelling of occupant behaviour is increasingly being understood as important for modelling the energy demand of buildings. In the modelling of residential energy demand, the stochastic person-based approach is useful to predict realistic time-series energy demand. The time-inhomogeneous Markov Chain Monte Carlo technique is the most frequently used method to model the occupancy and activity of building occupants (e.g. Richardson et al. 2010, Widén et al. 2012). Wilke et al. (2013) model activity as a sequence of discrete events with a start time and duration. These models generally use time-use data (TUD) collected from people who submitted activity records, known as a time-use diary, in which they describe their activity on survey days.

The model performance generally depends on the adopted mathematical modelling algorithm as well as the data used for modelling. This paper focuses especially on the latter element, data preparation for activity modelling. O'Brien et al. (2016) classified data preparation approaches to address the heterogeneity in occupant behaviour into the following four categories: 1) use of sample distribution developed based on aggregated sample data, 2) consideration of clusters in sample data, 3) development of model (typically regression model) based on aggregated sample data, and 4) use of hierarchical modelling. This issue has not been well explored in the modelling of people's activity.

In the stochastic person-based approach, the first category is not very useful as TUD is a collection of data spanning a period of a few days and collected from a large number of people. Sequential time-use records are not available. Approaches two to four, however, can be applied to stochastic person-based modelling. Figure 1 illustrates the application of these approaches. In the clustering approach, TUD is first classified based on demographic conditions or characteristics in time use described in the data (e.g. the pattern of occupancy at home). Modelling parameters are developed based on TUD classified in each cluster. Household size is the most frequently used factor to develop clusters (e.g. Richardson et al. 2010). The most detailed classification in the literature is reported by Yamaguchi et al. (2017), who categorised TUD into 59 segments according to the major demographic categories, i.e. age, gender, employment status, and household composition. However, an increase in the number of clusters may result in a paucity of TUD for the development of modelling parameters (Wilke et al. 2013). In the third regression approach, the entire set of TUD is used to develop regression models of modelling parameters. For example, Wilke et al. (2013) developed multinomial logistic (mlogit) models to quantify the probability of starting activities considering twenty demographic conditions, including occupants' health, life stage, and city scale. In the fourth hierarchical modelling approach, the previous two approaches are combined. After classifying TUD into several major segments, regression models are developed for each TUD segment. The benefit of this approach is that the difference in the influence of predictor variables on modelling parameters among TUD segments can be considered. The application of this approach has not been observed in the literature.

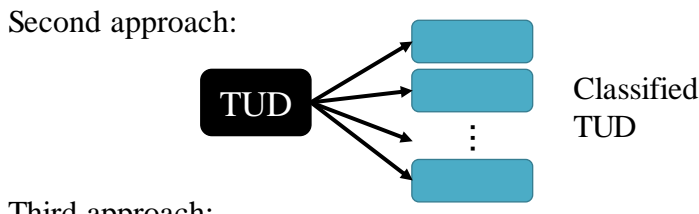

Third approach:
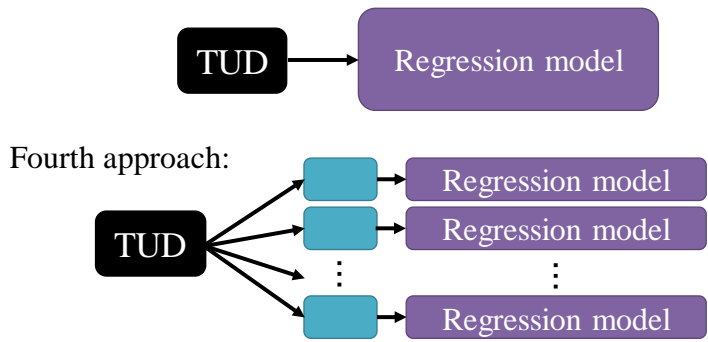

Figure 1: Application of the second, third, and fourth of O'Brien's approaches 
Based on the approaches outlined above, this paper evaluates how the variability of time use among simulated occupants changes when using the second, third, and fourth approaches of O'Brien et al.'s classification. The paper focuses on the probability of undertaking activities as the prepared modelling parameter that is given to simulated individuals considering their demographic conditions.

In the remainder of the paper, the method of evaluation, the model, and the TUD used in this study are presented first. Then, evaluation results are presented, followed by a discussion of the data preparation method considering the heterogeneity of occupant behaviour in stochastic person-based modelling.

\section{Method}

This paper evaluates the variability of the activity undertaking probability (AUP - the probability of a particular activity being undertaken at a particular time of day) as a modelling parameter of a stochastic personbased occupant behaviour model. Examples of models that use AUP as a modelling parameter include Richardson et al. (2010), Tanimoto et al. (2008), and Yamaguchi et al. (2017).

We designed four simulation cases for data preparation (Table 1) corresponding to approaches two to four of O'Brien's classification. Following an explanation of the TUD used in this study, details of each case and the method to quantify the AUP are explained.

Table 1: Four simulation cases

\begin{tabular}{|l|l|}
\hline Cases & Description \\
\hline \hline Case 1 & $\begin{array}{l}\text { Classifying TUD for six segments using the basic } \\
\text { demographic conditions listed in Table 2 }\end{array}$ \\
\hline Case 2 & $\begin{array}{l}\text { Classifying TUD for 59 segments using the } \\
\text { detailed demographic conditions listed in Table 3 }\end{array}$ \\
\hline Case 3 & $\begin{array}{l}\text { Developing a regression model based on the full } \\
\text { set of TUD }\end{array}$ \\
\hline Case 4 & $\begin{array}{l}\text { Classifying TUD for six segments by basic } \\
\text { demographic conditions and developing } \\
\text { regression models for each segment }\end{array}$ \\
\hline
\end{tabular}

\section{Data}

This study used TUD collected by the 2000 and 2005 Japanese time-use surveys (SBJ 2006). This survey incorporates both TUD and data on the demographic conditions of the survey participants. From the two survey formats available in the TUD, we selected the freeresponse format data, in which the respondents freely described the activities they undertook during the investigation period. We only used TUD surveyed on weekdays so as to focus on the influence of demographic conditions. The number of weekday samples was approximately 7,500. Eighty-five activity types were encoded from the activities described by respondents. In order to simplify the activity types, we reorganized into sixty-two activities. Fifty-nine home (in-home) activities and three away (external) activities for work, school, and other tasks were considered. To develop modelling parameters, the original 15-minute-interval TUD was aggregated into 1-hour-interval data by incorporating
TUD from each quarter hour recorded in the TUD for that hour (e.g., 0:00, 0:15, 0:30, and 0:45 for the 0:00 category).

\section{Case 1: Classification by the major demographic segments}

The first and second cases are based on the clustering approach. Demographic conditions and day types (weekdays or holidays) generally have a significant influence on how people use their time. In this study we considered age, gender, and employment/school status as the basic factors that characterise time use. In Case 1, we developed the modelling parameter by dividing the TUD into six clusters formed according to age, gender, and employment/school status, as listed in Table 2.

AUP was calculated by $N_{a c t, t} / N_{a l l}$, where $N_{a c t, t}$ is the number of survey participants who conducted the target activity and $N_{\text {all }}$ is the total number of survey participants.

Table 2: Classification and its definition in Case 1.

\begin{tabular}{|l|l|}
\hline Classification & Definition \\
\hline \hline Student & $\begin{array}{l}\text { Students studying at a primary, } \\
\text { junior high, or high school, or } \\
\text { university/college }\end{array}$ \\
\hline Adult male & $\begin{array}{l}\text { Male aged 20 to 59 who is not a } \\
\text { student }\end{array}$ \\
\hline Employed female & $\begin{array}{l}\text { Female aged 20 to 59, who is not a } \\
\text { student, with a job }\end{array}$ \\
\hline Unemployed female & $\begin{array}{l}\text { Female aged 20 to 59, who is not a } \\
\text { student, without a job }\end{array}$ \\
\hline Senior male & Male aged 60 or older \\
\hline Senior female & Female aged 60 or older \\
\hline
\end{tabular}

\section{Case 2: Classification by detailed segments}

In Case 2, AUP was quantified in the same manner as in Case 1 but 59 demographic segments listed in Table 3 were considered. The segments mirrored those described in Yamaguchi et al. (2017).

Table 3: Occupants' attributes used to develop demographic classifications in Case 2.

\begin{tabular}{|l|l|}
\hline Attribute & Condition \\
\hline Gender & (1) Male, (2) Female \\
\hline Age & $\begin{array}{l}\text { (1) Younger than 20, (2) 20 to 44, (3) 45 to } \\
64, \text { (4) 65 and older }\end{array}$ \\
\hline Occupation & (1) With paid work, (2) Without paid work \\
\hline $\begin{array}{l}\text { Age of } \\
\text { children }\end{array}$ & $\begin{array}{l}\text { Children where the youngest is (1) preschool, } \\
\text { (2) primary- to high-school student, and (3) } \\
\text { aged 18 and older }\end{array}$ \\
\hline Living alone & $\begin{array}{l}\text { (1) Living alone, (2) Living in a two-or- } \\
\text { more-person household }\end{array}$ \\
\hline Student & $\begin{array}{l}\text { (1) Primary school, (2) Junior high, (3) High } \\
\text { school, (4) University and college }\end{array}$ \\
\hline $\begin{array}{l}\text { Working } \\
\text { time } \\
\text { employed } \\
\text { male }\end{array}$ & $\begin{array}{l}\text { (1) Full-time worker with morning and } \\
\text { afternoon shifts, (2) Long-shift worker with } \\
\text { longer working times than (1), (3) Worker } \\
\text { with afternoon and night shifts }\end{array}$ \\
\hline $\begin{array}{l}\text { Working } \\
\text { time for } \\
\text { employed } \\
\text { female }\end{array}$ & $\begin{array}{l}\text { (1) Full-time worker with morning and } \\
\text { afternoon shifts, (2) Long-shift worker with } \\
\text { longer working times than (1), (3) Worker } \\
\text { with afternoon and night shifts, (4) Morning } \\
\text { worker, and (5) Afternoon part-time worker }\end{array}$ \\
\hline
\end{tabular}




\section{Case 3: Regression approach}

Case 3 is based on the third approach of O'Brien et al.'s classification. Wilke et al.'s (2013) study, which models activity-starting probability, can be classified under this approach. The modelling parameter was quantified by using the regression model shown in Equation (1), developed based on the full TUD sample:

$$
\ln \frac{p_{t}}{1-p_{t}}=\beta_{0, t}+\sum_{i=1}^{n} \beta_{i, t} x_{i},
$$

where $p_{t}$ is the AUP at time $t, \beta_{0, t}$ is the intercept at time $t$, and $\beta_{i, t}$ is the partial regression coefficient of explanatory variable $x_{i}$ at time $t(t=1 \sim 24)$. By assigning predictor variables, $p_{t}$ can be quantified by Equation (2):

$$
p_{t}=\frac{1}{1+\exp \left\{-\left(\beta_{0, t}+\sum_{i=1}^{n} \beta_{i, t} x_{i}\right)\right\}} .
$$

The predictor variables of the regression model are the demographic conditions listed in Table 4. In addition to the demographic conditions used in Case 2, various other conditions were considered, such as ownership of the house (owner or tenant), city size, household composition, and nature of occupation. The stepwise selection of predictors was conducted so that Akaike's Information Criterion (AIC) could be minimised in the regression analysis.

\begin{tabular}{|c|c|}
\hline Index & Variables \\
\hline Survey year & (1) 2001, (2) 2006* \\
\hline City size & (1) Urban area, (2) Non-urban area* \\
\hline Gender & (1) Male*, (2) Female \\
\hline School status & $\begin{array}{l}\text { (1) Primary school, (2) Secondary } \\
\text { school, (3) High school, (4) University, } \\
\text { (5) Non-education* }\end{array}$ \\
\hline $\begin{array}{l}\text { Employment } \\
\text { status }\end{array}$ & $\begin{array}{l}\text { (1) Full-time worker*, (2) Part-time } \\
\text { worker, (3) Unemployed }\end{array}$ \\
\hline Homeownership & (1) Owner*, (2) Tenant, (3) Other \\
\hline Age & $\begin{array}{l}\text { (1) } 10 \sim 19, \text { (2) } 20 \sim 29, \text { (3) 30 44*, (4) } \\
45 \sim 59, \text { (5) 60 74, (6) } 75 \text { and older }\end{array}$ \\
\hline $\begin{array}{l}\text { Household } \\
\text { composition }\end{array}$ & $\begin{array}{l}\text { (1) Couple without children, (2) Couple } \\
\text { with children*, (3) Couple with parents, } \\
\text { (4) } 3 \text { generations, (5) Single, (6) Other }\end{array}$ \\
\hline $\begin{array}{l}\text { Excision } \\
\text { preschool }\end{array}$ & $\begin{array}{l}\text { (1) With a preschool child, (2) Without } \\
\text { preschool children* }\end{array}$ \\
\hline $\begin{array}{l}\text { Nature of } \\
\text { occupation }\end{array}$ & $\begin{array}{l}\text { (1) Professional and technical workers, } \\
\text { (2) Managers and officials, (3) Clerical } \\
\text { and related workers, (4) Sales workers, } \\
\text { (5) Protective service workers and } \\
\text { service workers, (6) Agricultural, } \\
\text { forestry and fishery workers, (7) Workers } \\
\text { in transportation and communication- } \\
\text { related occupations, (8) Craftsmen, mine } \\
\text { workers, manufacturing and construction } \\
\text { workers, labourers* }\end{array}$ \\
\hline
\end{tabular}

Table 4: Predictor variables of the regression model

A dummy variable related to the survey year was used as a predictor variable to eliminate the influence of the difference in the survey year. This research uses the population density of a region to distinguish urban from non-urban regions, with urban areas having a higher population density than non-urban areas. It should be noted that the variables marked with $*$ in Table 4 were used as reference demographic categories when the regression models were developed.

\section{Case 4: Integrated approach}

Finally, Case 4, based on the fourth approach of O'Brien's classification, combines Cases 1 and 3. The modelling parameter was quantified by regression models developed for the same 6 segments of TUD as Case 1 (Table 2). Table 5 shows the demographic reference conditions used

\begin{tabular}{|c|c|}
\hline Classification & Reference demographic conditions \\
\hline Student & $\begin{array}{l}\text { Male studying at a secondary school living } \\
\text { in a non-urban area }\end{array}$ \\
\hline Adult male & $\begin{array}{l}\text { Male aged } 30 \text { to } 44 \text { with a full-time job } \\
\text { living in a household with children but } \\
\text { without preschool children. House owner } \\
\text { living in non-urban area. Artisan, mine } \\
\text { worker, or manufacturing or construction } \\
\text { worker }\end{array}$ \\
\hline $\begin{array}{l}\text { Employed } \\
\text { female }\end{array}$ & $\begin{array}{l}\text { Female aged } 30 \text { to } 44 \text { with a full-time job } \\
\text { living in a household with children but } \\
\text { without preschool children. House owner } \\
\text { living in a non-urban area. Artisan, mine } \\
\text { worker, or manufacturing or construction } \\
\text { worker. }\end{array}$ \\
\hline $\begin{array}{l}\text { Unemployed } \\
\text { female }\end{array}$ & $\begin{array}{l}\text { Female aged } 30 \text { to } 44 \text { without a job living in } \\
\text { a household with children but without } \\
\text { preschool children. Living in an owner- } \\
\text { occupied house in a non-urban area. }\end{array}$ \\
\hline Senior male & $\begin{array}{l}\text { Male aged } 60 \text { to } 74 \text { living in a couple } \\
\text { household and in an owner-occupied house. }\end{array}$ \\
\hline $\begin{array}{l}\text { enior } \\
\text { emale }\end{array}$ & $\begin{array}{l}\text { Female aged } 60 \text { to } 74 \text { living in a couple } \\
\text { household and in an owner-occupied house. }\end{array}$ \\
\hline
\end{tabular}
in the models for each segment.

\section{Result of logistic regression analysis}

This chapter describes the results of the regression analyses conducted in Cases 3 and 4. Table 6 lists the regression coefficient (RC) and odds ratio (OR) quantified in the logistic regression analyses in Cases 3 and 4 for an AUP of sleeping at $11 \mathrm{pm}$. The displayed results of Case 4 are those of the employed female segment. The blank cells indicate that the variables were recognised as insignificant by the stepwise method. For Case 4, the variables that were not used in the development of the regression models are indicated by blank cells with a diagonal line.

The regression coefficients indicate how predictor variables change the right side of Equation (1) for the AUP of sleeping at $11 \mathrm{pm}$ compared to the reference condition. Therefore, the influence of each factor cannot be simply compared between Cases 3 and 4 . The odds ratios indicate how the odds change with changes in the corresponding predictor variables. The larger the deviation from 1 in the value of the odds ratio, the more significant an influence the predictor variables have on AUP. The results of Case 3 indicate that senior people 
Table 6: Results of logistic regression analysis in Case 3 and Case 4 for AUP of sleeping at 11 pm in terms of estimate and $p$-value.

\begin{tabular}{|c|c|c|c|c|c|c|c|c|c|c|c|}
\hline \multirow{2}{*}{ Index } & \multirow{2}{*}{ Variable } & \multicolumn{2}{|l|}{ Case 3} & \multicolumn{2}{|l|}{ Case 4} & \multirow{2}{*}{ Index } & \multirow{2}{*}{ Variable } & \multicolumn{2}{|l|}{ Case 3} & \multicolumn{2}{|l|}{ Case 4} \\
\hline & & $\mathrm{RCs}$ & ORs & $\mathrm{RCs}$ & ORs & & & $\mathrm{RCs}$ & ORs & RCs & ORs \\
\hline $\begin{array}{l}\text { Survey } \\
\text { Year }\end{array}$ & 2001 & - & - & 0.07 & 1.07 & \multirow{6}{*}{$\begin{array}{l}\text { House- } \\
\text { hold } \\
\text { compo- } \\
\text { sition }\end{array}$} & $\begin{array}{l}\text { Couple without } \\
\text { child }\end{array}$ & $-0.17 * * *$ & 0.84 & - & - \\
\hline Gender & Female & - & - & & & & Couple with parent & $0.33^{* * * *}$ & 1.39 & $0.41^{* * *}$ & 1.51 \\
\hline \multirow{4}{*}{$\begin{array}{l}\text { School } \\
\text { status }\end{array}$} & $\begin{array}{l}\text { Primary } \\
\text { school }\end{array}$ & $\begin{array}{l}3.67 * * \\
*\end{array}$ & 39.1 & & & & $\begin{array}{l}\text { Couple with } 3 \\
\text { generations }\end{array}$ & $0.09 * *$ & 1.1 & - & - \\
\hline & $\begin{array}{l}\text { Secondary } \\
\text { school }\end{array}$ & $1.48 * *$ & 4.4 & & & & Singles & $-0.37 * * *$ & 0.69 & $-0.42 * * *$ & 0.66 \\
\hline & High school & $0.38 * *$ & 1.46 & & & & Others & - & - & $-0.12 *$ & 0.88 \\
\hline & University & -0.13 & 0.88 & & & & $\begin{array}{l}\text { With preschool } \\
\text { children }\end{array}$ & $0.38 * * *$ & 1.46 & $0.81 * * *$ & 2.25 \\
\hline \multirow{2}{*}{$\begin{array}{l}\text { Employ- } \\
\text { ment } \\
\text { status }\end{array}$} & Part-time & $-0.08 *$ & 0.92 & - & - & \multirow{7}{*}{$\begin{array}{l}\text { Occu- } \\
\text { pation }\end{array}$} & $\begin{array}{l}\text { Professional and } \\
\text { technical workers }\end{array}$ & $-0.66 * * *$ & 0.52 & $-0.40 * * *$ & 0.67 \\
\hline & No work & $0.13 * *$ & 0.87 & & & & $\begin{array}{l}\text { Clerical and } \\
\text { related workers }\end{array}$ & $-0.49 * * *$ & 0.61 & $-0.48 * * *$ & 0.62 \\
\hline \multirow{2}{*}{$\begin{array}{l}\text { Housing } \\
\text { owner- } \\
\text { ship }\end{array}$} & Rent & $\overline{0} .21 * *$ & 0.81 & $-0.17 * *$ & 0.84 & & Sales workers & $-0.62 * * *$ & 0.54 & $-0.67 * * *$ & 0.51 \\
\hline & Others & - & - & - & - & & $\begin{array}{lr}\text { Protective } & \text { service } \\
\text { workers } & \text { and } \\
\text { service workers }\end{array}$ & $-0.57 * * *$ & 0.57 & $-0.53 * * *$ & 0.58 \\
\hline \multirow{4}{*}{ Age } & $\begin{array}{l}\text { Aged } 10 \text { to } \\
19\end{array}$ & $0.92 * *$ & 0.4 & & & & $\begin{array}{l}\text { Agricultural, } \\
\text { forestry, and } \\
\text { fishery workers }\end{array}$ & $0.71 * * *$ & 2.03 & $0.50 * * *$ & 1.65 \\
\hline & Aged 20 to & $\begin{array}{l}-\overline{0} 33 * * \\
*\end{array}$ & 0.72 & $-0.14^{*}$ & 0.87 & & $\begin{array}{l}\text { Workers in } \\
\text { transport and } \\
\text { communication } \\
\text { industry }\end{array}$ & $-0.51 * * *$ & 0.6 & $-1.23 * * *$ & 0.29 \\
\hline & $\begin{array}{l}\text { Aged } 45 \text { to } \\
59\end{array}$ & $0.65 * *$ & 1.91 & $0.56 * *$ & 1.75 & & Others & - & - & - & - \\
\hline & $\begin{array}{l}\text { Aged } 60 \text { to } \\
74\end{array}$ & $1.55^{* *}$ & 4.7 & & & $\begin{array}{l}\text { City } \\
\text { size }\end{array}$ & Urban & $-0.48 * * *$ & 0.62 & $-0.46 * * *$ & 0.63 \\
\hline \multicolumn{6}{|c|}{$* * *:<0.001, * *:<0.01, *:<0.05$} & \multicolumn{2}{|c|}{ (Intercept) } & $0.65 * * *$ & 1.92 & $0.52 * * *$ & 1.68 \\
\hline
\end{tabular}

aged 60 or older have a higher AUP. Students with a higher level of schooling have a lower AUP than their counterparts. People living alone have a lower AUP than people from a household of two or more. People with preschool children have a higher AUP than their counterparts. People renting a home and living in an urban area have a lower AUP. The displayed results of Case 4 are again those of the employed female segment, and predictor variables with diagonal lines were not considered in the regression. Comparing Cases 3 and 4, the influence on AUP of the existence of preschool children in Case 4 is larger than that in Case 3 that includes the influence of both males and females. No significant difference was observed between full-time and part-time workers. The influence of age is weaker than in Case 3. The influence of occupation is similar to its impact in Case 3, except for workers in agricultural, forestry, and fishery, and workers in transport and communication industries - these exhibited a weaker influence than in Case 3. These differences between Case 3 and Case 4 can be attributed to the consideration of six demographic segments and to the fact that the influence of the predictor variables differs between the different demographic segments.

The developed models were validated by the HosmerLemeshow goodness-of-fit test (Helbe 2006). Figure 2 shows p-values estimated by the goodness-of-fit test for the regression models developed for each time of day in Cases 3 and 4, where the results for employed females are shown in Case 4. The p-values smaller than 0.05 indicate that the developed models differ significantly from the original TUD. In Case 3, the p-values were smaller than
0.05 for six hours of the day. In Case 4 the p-value at 22:00 was smaller than 0.05. Figure 3 shows the number of the hours of the day for which the p-values were larger than 0.05 for the regression models for sleeping, working, cooking, and TV/radio usage. In Case 4, the values were quantified for the 6 demographic segments. Larger values for Case 3 than Case 4 indicate that Case 4 performs better than Case 3.

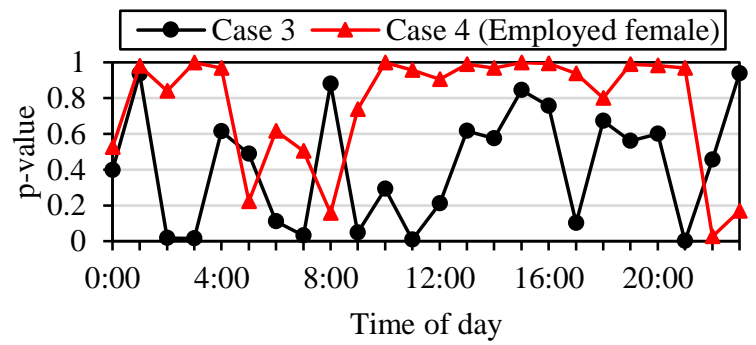

Figure 2: P-values of the goodness-of-fit test conducted for the regression models developed in Cases 3 and 4

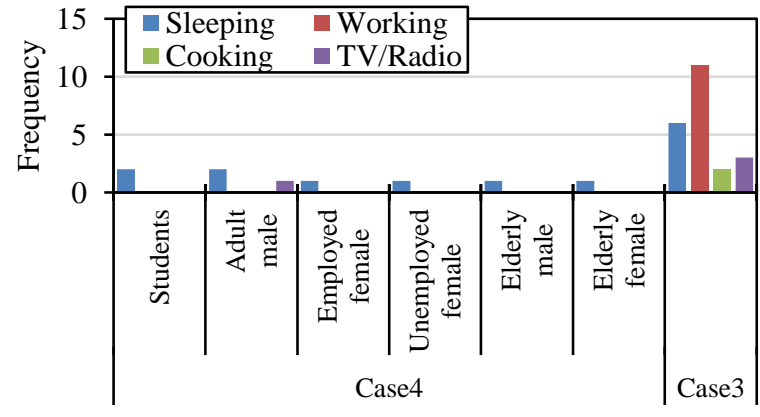

Figure 3: Number of hours of day at which a significant difference from the original TUD was observed 


\section{Evaluation of variability}

\section{Evaluation method}

This section evaluates the variability in AUP for the models developed in Cases 1 to 4 for selected activities.

The considered activities are listed in Table 7, with the influence of demographic conditions (listed in the second column of the table) evaluated for each.

\section{Result}

Figure 4 shows the AUP of TV/radio at each time of day estimated by the models developed in the four cases for the demographic segments with different gender/age values. In Case 1, people aged 60 or older were estimated to have a higher AUP from 6 am to $8 \mathrm{pm}$ than the other demographic segments. Case 2 showed a similar trend, despite exhibiting wider variation than Case 1. Case 4 showed similar variation to Case 2. Case 3 exhibited
Table 7: List of estimated activities and people's attribute

\begin{tabular}{|l|l|}
\hline Activity & $\begin{array}{l}\text { Influential demographic conditions that } \\
\text { were evaluated }\end{array}$ \\
\hline \hline TV/radio & People with different genders and ages \\
\hline Working & $\begin{array}{l}\text { People with different employment statuses } \\
\text { (Full-time worker was assumed for male, } \\
\text { whereas part-time was assumed for } \\
\text { female.) }\end{array}$ \\
\hline Cooking & $\begin{array}{l}\text { Employed females with different } \\
\text { household composition and different } \\
\text { condition on the existence of pre-school } \\
\text { child. }\end{array}$ \\
\hline Sleeping & $\begin{array}{l}\text { Adult male living in an area with different } \\
\text { city size and with a house ownership } \\
\text { condition. }\end{array}$ \\
\hline
\end{tabular}

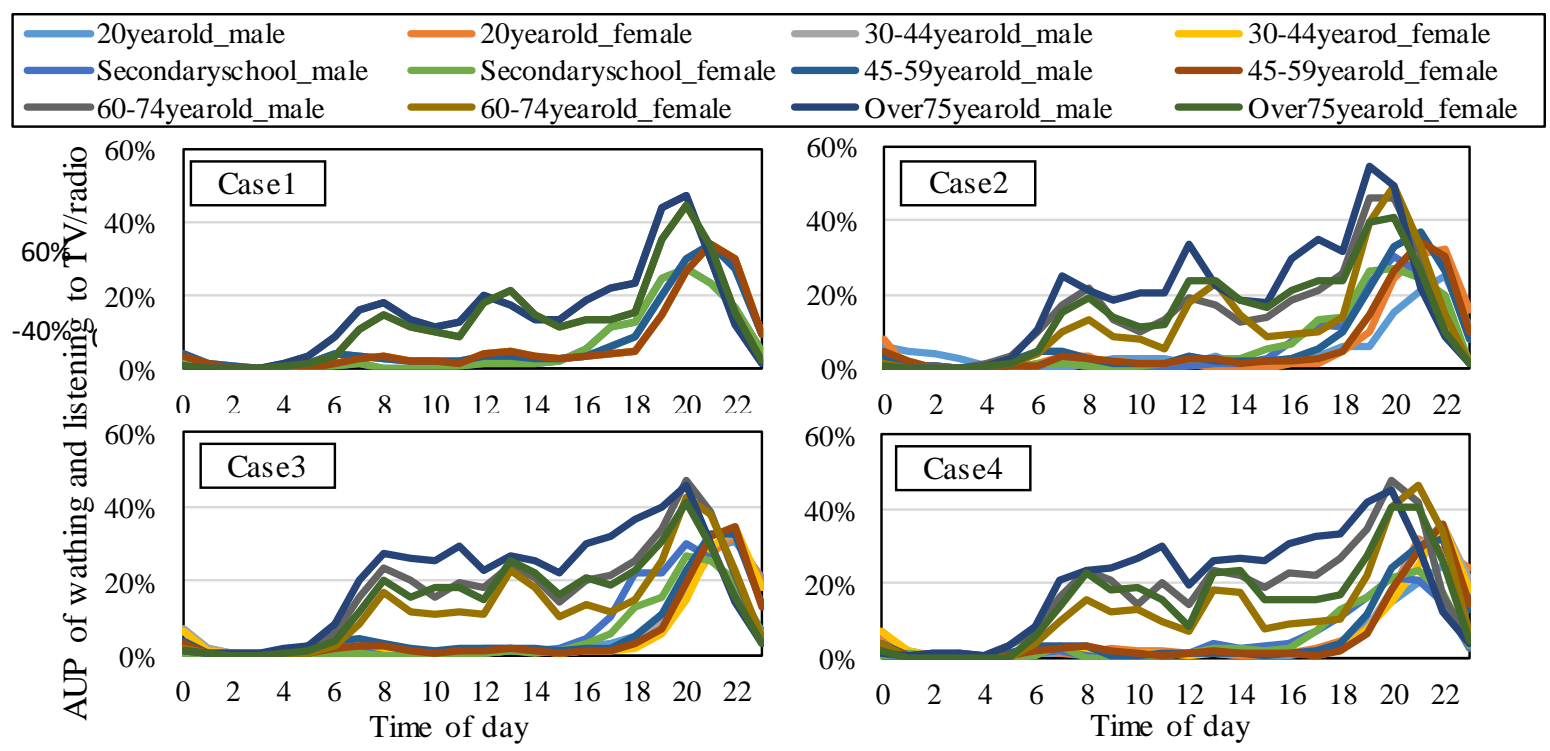

Figure 4: AUP of watching or listening to TV/radio in time series

\begin{tabular}{|rrr|}
\hline Fulltime_Occupation2 & Parttime_Occupation2 & Fulltime_Occupation3 \\
Fulltime_Occupation4 & Parttime_Occupation4 & Parttime_Occuaption3 \\
Fulltime_Occupation7 & Parttime_Occupation7 & \\
\hline
\end{tabular}

$80 \%$

$70 \%$

$60 \%$

$50 \%$

$40 \%$

$30 \%$

$20 \%$

$10 \%$

Figure 5: AUP of working in time series 


\begin{tabular}{|c|c|c|}
\hline $\begin{array}{l}\text { Single } \\
\text { Couple_with_schoolchild } \\
3 \text { generation with preschool }\end{array}$ & $\begin{array}{l}\text { Young_couple_without_child } \\
\text { Couple_with_preschool }\end{array}$ & $\begin{array}{l}\text { Old_couple_without_child } \\
\text { 3_generation_without_preschool }\end{array}$ \\
\hline
\end{tabular}
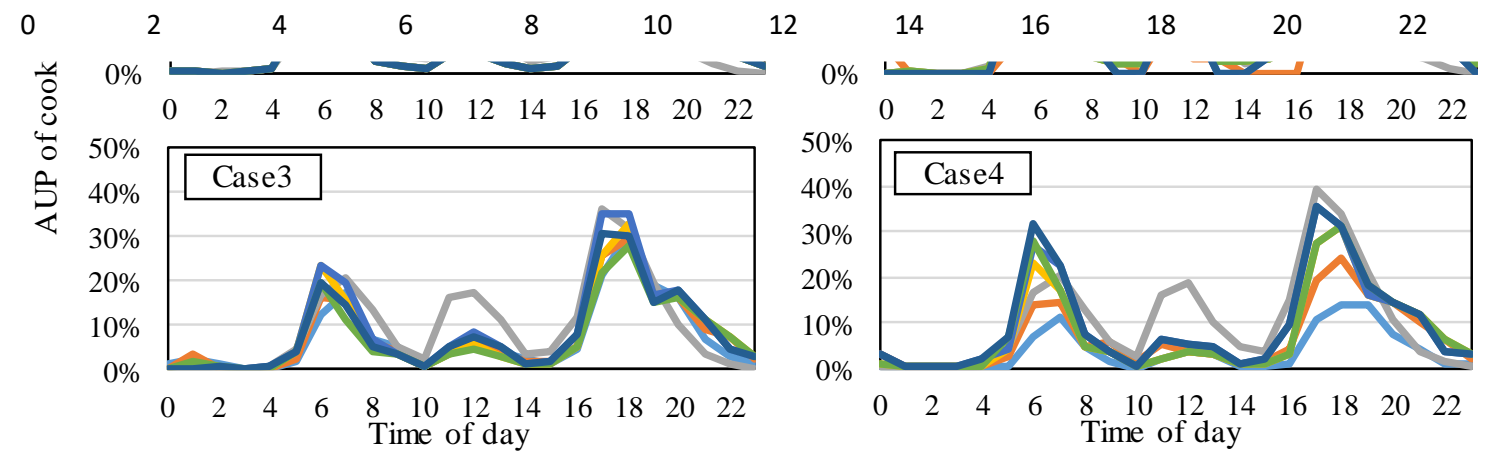

Figure 6: AUP of cooking in time series

slightly narrower variation than Case 4 . This difference is due to the influence of predictor variables among the six segments considered in Case 4.

Figure 5 shows the AUP of working with various combinations of the employment status and nature of occupation values (Table 4). Cases 1 and 2 show only three profiles depending on the employment status since the nature of occupation was not taken into account when the clusters were developed. On the contrary, Cases 3 and 4 show a significant variation in AUP.

Figure 6 shows the AUP of cooking. As shown in Cases 2 and 4, the household composition, including the existence of preschool children, has a significant influence. Case 1 showed the smallest variation as this case ignored the influence of household composition. Case 3 shows a smaller variation than Case 4. This difference is because the time spent cooking is significantly different between males and females and the influence of household composition is levelled, i.e. underestimated for females and overestimated for males. The model in Case 4 is capable of considering and representing this, as this case reflects the influence of household composition among each of the six demographic segments respectively.

Figure 7 shows the AUP of sleeping at $11 \mathrm{pm}$ estimated for a working male. City size and homeownership were considered to be the influencing factors here. Cases 1 and 2 show the same values for the four conditions as the influence of the city size and homeownership were ignored. In contrast, Cases 3 and 4 capture their influence, as the AUP of sleeping for people living in an urban area is lower than that of their non-urban counterparts. Furthermore, the AUP of sleeping for homeowners is higher than for tenants for both urban and non-urban areas. It should be noted that the results of Case 3 were slightly larger than those of Case 4 , a difference resulting from the difference in the influence of occupation. The clerical and related workers have a lower AUP in Case 4 than those in Case 3.

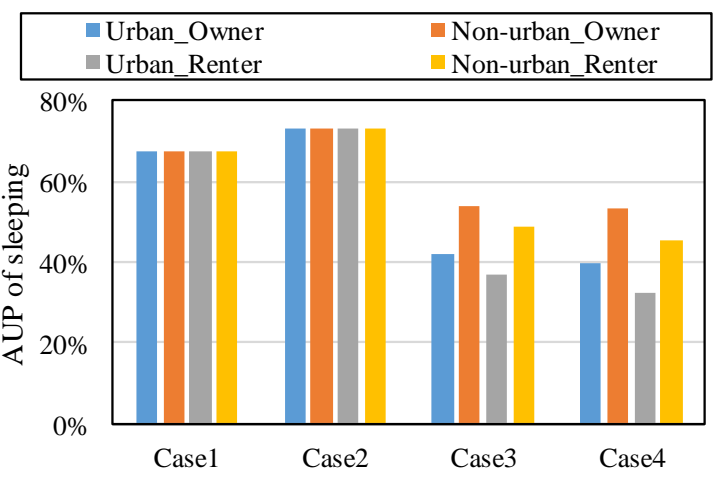

Figure 7: AUP of sleeping at $11 \mathrm{pm}$

\section{Application in community-scale modelling}

In previous sections, we estimated the AUP of people who met certain demographic conditions. In this section, the AUP of people living in a specific postcode district located in Tokyo, Japan, is estimated. The simulated households were randomly generated by the household generation model based on population census data (Kambayashi et al. 2018, Yamaguchi et al. 2019). The generated households were a combination of household members with specific demographic conditions so that predictor variables considered in the regression analysis of the AUP were assigned to simulated individuals.

The studied postcode district comprised 673 households, with 1059 residents in total, excluding preschool children whose activity was not modelled in this study. Figure 8 shows the distribution of the gender, household composition, employment status, and homeownership of the residents and households in the area. People aged 20 to 59 account for $67 \%$ of the total. More than $60 \%$ are single households; $40 \%$ of people have a fulltime job; $40 \%$ of people are unemployed; $60 \%$ of households are rented. In addition, the focus district is located in an urban area, and $75 \%$ of employed people were assumed to be in employed in tertiary industry in the area. 


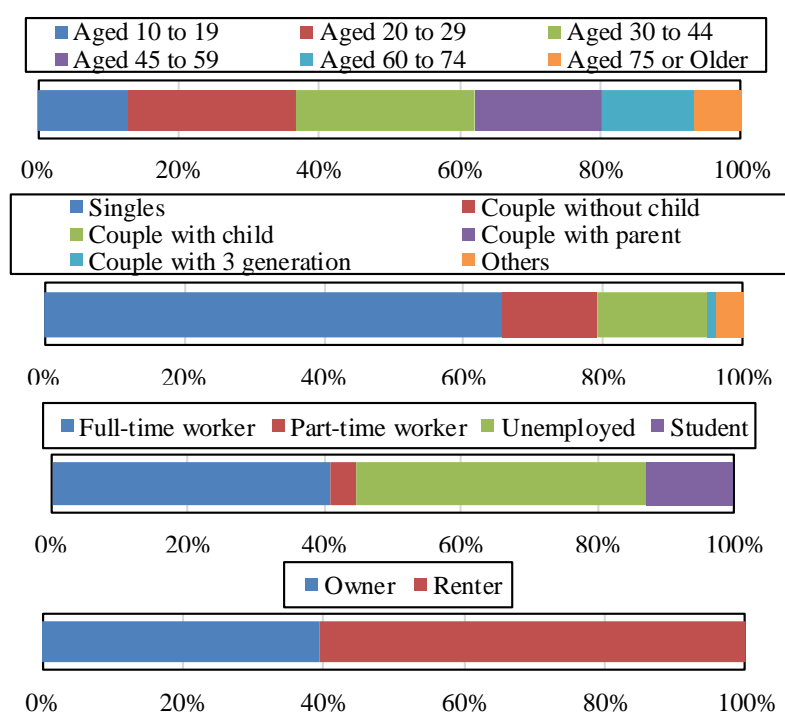

Figure 8: Composition of the residents and households living in the target postcode district (top down: resident's age, rate of household composition, employment/school status of residents, and homeownership)

\section{Result}

Figure 9 shows box plots of residents' predicted AUP of sleeping at $11 \mathrm{pm}$. The dots on the figure represent the AUP of individuals, the crosses represent the mean, and the horizontal lines across the boxes represent the median.

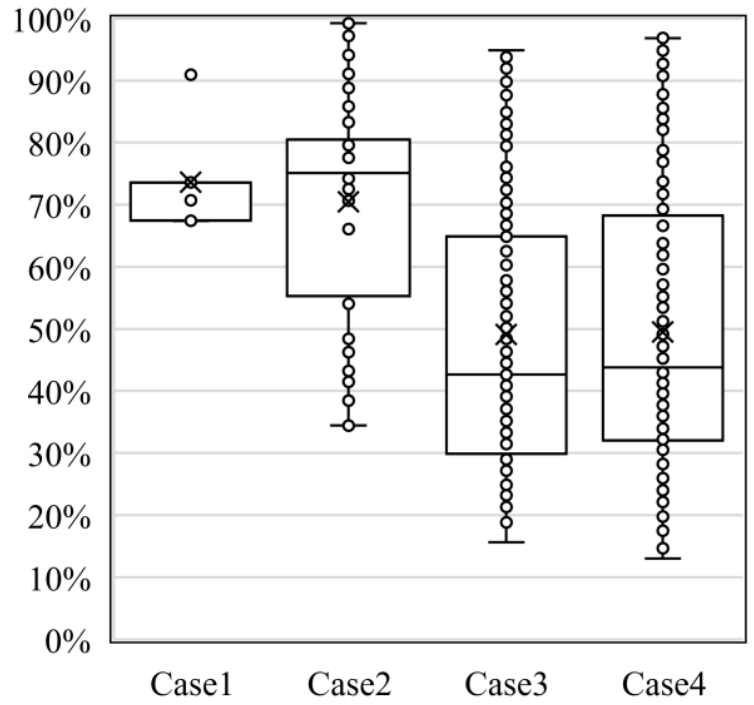

Figure 9: Box plot of predicted AUP for sleeping at 11 pm $(N=1059)$

It can be seen that Case 1 showed the narrowest variation as this case only considers the six demographic clusters. There are two notable differences between the other cases. First, Case 2 showed 59 values depending on the number of demographic clusters, whereas the AUP in Cases 3 and 4 is more continuously distributed. This result shows the benefit of using regression modelling capable of considering the influence of a greater number of factors. Second, the mean value is different between the three cases. The mean value is the highest in Case 2 and the lowest in Case 3. This difference can be attributed to the influence of the predictor of city size, homeownership, and occupation that were considered in Cases 3 and 4. The case study area is urban, which decreases the AUP of sleeping at $11 \mathrm{pm}$. The proportion of people renting is higher than those owning homes in the area, with tenants having a smaller AUP than owners. The proportion of employed residents in tertiary industry is high (75\%) which decreases the AUP of sleeping at $11 \mathrm{pm}$.

Figure 10 shows the cumulative frequency of AUP of (from the bottom up) sleeping at $11 \mathrm{pm}$, working at $9 \mathrm{am}$, cooking at $6 \mathrm{pm}$ and TV/radio at $8 \mathrm{pm}$ estimated for the residents. Significant differences were observed between the compositions of the four cases. The variation was the smallest in Case 1. Cases 3 and 4 showed wider variability in the AUP of working than Case 2, as can be seen in Figure 5. A large difference was observed between the AUPs of cooking for the different cases (Figure 6). The results indicated that the regression approach is capable of generating more variability in activity profiles among residents and households than the approach only using clustering.

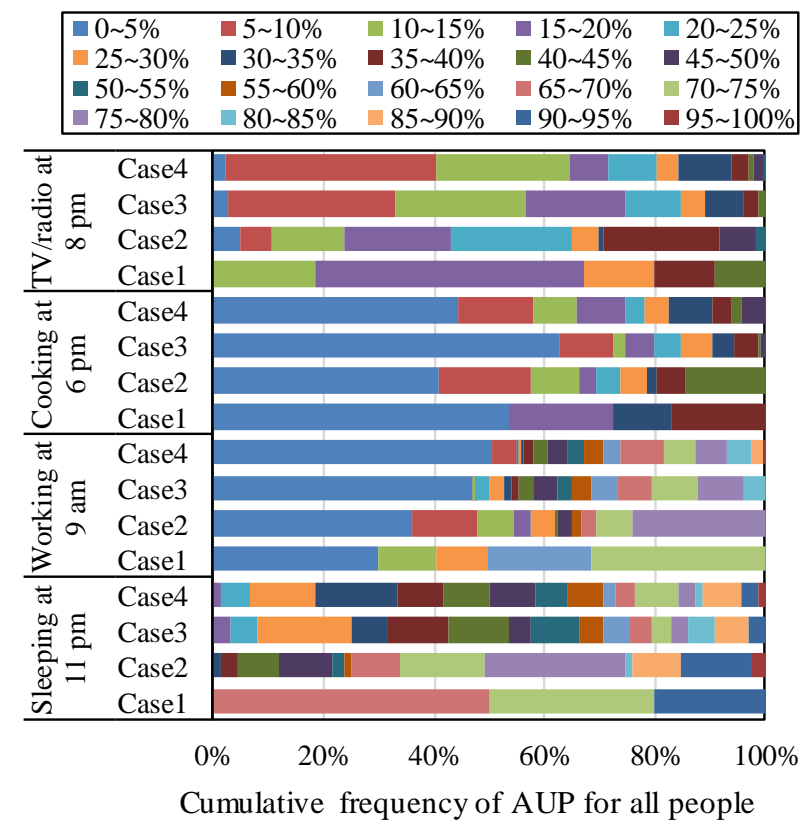

Figure 10: Cumulative frequency of AUP of sleeping, working, cooking, and TV/radio

\section{Discussion}

This paper evaluated how the data preparation process influences model performance, focusing especially on the capability of reflecting the influence of demographic conditions on time use. This issue is important to address in order to be able to consider the heterogeneity in activity and resultant energy demand in stochastic person-based residential energy-demand models. Comparing the three data preparation approaches, namely consideration of clusters in sample data, development of the model (typically regression model) based on aggregated sample data, and the hierarchical approach integrating the previous two approaches, we derived the following findings. 
- Ignorance of the influence of demographic conditions may result in a significant error in the modelling of occupant behaviour and less variability in the results. Clustering and regression modelling are useful to address the issue.

- The modelling approach using a regression model is effective for the consideration of various demographic conditions. Although the clustering approach is also capable of considering various factors, the increase in considered factors decreases the sample TUD quantity within each cluster. The regression approach does not suffer from this data paucity issue.

- In the regression approach, the hierarchical approach is useful to enhance the variability of modelling parameters, because the influence of various factors is dependent on other factors. The results of the goodness-of-fit test also supported this finding.

\section{Conclusion}

This paper evaluated how data preparation approaches influence the variability in the result of stochastic personbased occupant behaviour models. The variability of the clustering approach can be enhanced by increasing the number of clusters, which may result in an unexpected error since the number of TUD used to develop modelling parameters decreases. The regression approach is not subject to this data paucity problem. Because the influence of demographic conditions is dependent on other conditions, the hierarchical approach, integrating the clustering and regression approaches, is more appropriate for data preparation to enhance variability among simulated occupants. For example, the time allocation of housework is heavily dependent on gender in Japan.

The findings imply the necessity of further research. Initially, a method should be determined to develop appropriate clusters in the hierarchical approach. As such, the hierarchical relationship among influential factors needs to be better understood. Although basic demographic conditions were used in this study, clustering based on characteristics in time use, e.g. occupancy pattern, should also be considered (Aerts et al. 2014). Moreover, the application of stochastic personbased occupant behaviour models should be further explored as these contribute to providing more realistic time-series data on occupant behaviour for energy demand modelling.

\section{Acknowledgement}

This work was supported by JST CREST under Grant JPMJCR15K4, Japan.

\section{References}

Aerts, D., Minnen, J., Glorieux, I., Wouters, I., and Descamps, F. (2014). "A Method for the Identification and Modelling of Realistic Domestic Occupancy Sequences for Building Energy Demand Simulations and Peer Comparison." Building and Environment 75: 67-78. doi:10.1016/j.buildenv.2014.01.021.
Helbe, J. M. "Analysis of Model fit." In Chap. 7 in Logistic Regression Models, 243-296. Boca Raton: CRC Press.

Kambayashi, Y., Yamaguchi, Y., Taniguchi-Matsuoka, A., Shimoda, Y. 2018, Census and time-use data based community-scale modelling of residential energy demand, Proceedings of ASim2018.

Richardson, I., Thomson, M., Infield, D., and Clifford, C. (2010). Domestic Electricity Use: A High-Resolution Energy Demand Model. Energy and Buildings 42 (10): 1878-1887. doi:10.1016/j.enbuild.2010.05.023.

Statistics Bureau of Japan (SBJ), Ministry of Internal Affairs and Communications. 2006 Survey on time use and leisure activities.

Tanimoto, J., Hagishima, A., and Sagara, H. (2008). "Validation of Methodology for Utility Demand Prediction Considering Actual Variations in Inhabitant Behaviour Schedules." Journal of Building Performance Simulation 1: 31-42. doi:10.1080/19401490701868471.

Widén, J., Molin, A., \& Ellegård, K. (2012). Models of domestic occupancy, activities and energy use based on time-use data: deterministic and stochastic approaches with application to various buildingrelated simulations. Journal of Building Performance Simulation, 5(1), 27-44. https://doi.org/10.1080/19401493.2010.532569

Wilke, U., Haldi, F., Scartezzini, J.-L., \& Robinson, D. (2013). A bottom-up stochastic model to predict building occupants' time-dependent activities. Building and Environment, 60, 254-264.

O’Brien, W., Gunay, H. B., Tahmasebi, F., and Mahdavi. A. (2016). A preliminary study of representing the inter-occupant diversity in occupant modelling. Journal of Building Performance Simulation, http://dx.doi.org/10.1080/19401493.2016.1261943

Yamaguchi, Y., \& Shimoda, Y. (2017). A stochastic model to predict occupants' activities at home for community-/urban-scale energy demand modelling. Journal of Building Performance Simulation, 10, 565581.

Yamaguchi, Y., Yilmaz, S., Prakash, N., Firth, S.K., Shimoda, Y. (2019). A cross analysis of existing methods for modelling household appliance use. J. Build. Perform. Simul. 12, 160-179. https://doi.org/10.1080/19401493.2018.1497087 